\title{
The Validity of the Student Worksheets about The Moral Dilemma of Environmental Change through Solving Wetland Problems
}

\author{
Aminuddin Prahatama Putra, Olfia Ekasari \\ Biology Education \\ University of Lambung Mangkurat \\ Banjarmasin, Indonesia \\ aminuddinpatra@ulm.ac.id, Oolfiaekasari@gmail.com
}

\begin{abstract}
This study aims to describe the validity of worksheet on the concept of Environmental Change using the solution to the developed wetland problem. Problem-solving models are learning models that can be used related to answers to wetland environmental problems on the concept of environmental change. The validity of the worksheet is viewed from the six aspects, namely the material, linguistic, presentation, format, bibliography and particular elements of the model for solving wetland problems. The worksheet was validated by two validators, consisted of biology education lecturers. It was found that the validity of the spreadsheet an average for all aspects of 91.6\% which is categorized as a very feasible category. Based on the results, it can be concluded that the spreadsheet of environmental change concept using a model for resolving the developed wetland problem is valid.
\end{abstract}

Keywords—validity; worksheet; problem-solving; wetlands

\section{INTRODUCTION}

The Basic and Secondary Education Process Standards state that the preparation of learning tools is part of learning planning. One of the learning tools is student worksheet. Student worksheet guides students to do specific tasks that can improve and strengthen learning outcomes. Ref [1] states that student worksheet is one of the learning resources in the form of sheets containing brief material, learning objectives, instructions on how to work on questions and some questions students must answer. The development of this student worksheet needs to be developed primarily for teachers to be able to link local potential with learning for students with the existence of this expanded student worksheet so that students can solve the problem of wetlands which is the local potential of Kalimantan which is associated with morals.

The feasibility of student worksheet can be viewed from its validity. Validity is an assessment carried out by reviewers including education experts, material experts, and biology teachers. Based on this explanation, the researcher aims to determine the validity of the student worksheet moral dilemma of environmental change through the resolution of the Class $\mathrm{X}$ High School wetland problem.

\section{METHOD}

This research applied development research (Research Development) method by using formative evaluation development model by Tessmer [2]. This development research produced a student worksheet through a model of solving a morally based wetland problem on the concept of the Environmental Change.

The development phase of the student worksheets was conducted at Lambung Mangkurat University Banjarmasin Indonesia. The trial phase was carried out on 11 students of science class of SMAN 3 Banjarmasin. The data was collected using a validated questionnaire. Two reviewers reviewed student worksheet from Biology Education of University Lambung Mangkurat. The validity of the student worksheets reviewed based on five aspects, namely material, linguistic, presentation, format, and bibliography aspects. The research instrument used by the reviewers was a validation sheet [3].

TABLE I.
\begin{tabular}{|l|l|}
\hline Percentage & Category \\
\hline $90 \%-100 \%$ & Very valid \\
\hline $75 \%-89 \%$ & Valid \\
\hline $65 \%-74 \%$ & Valid Enough \\
\hline $40 \%-64 \%$ & Less valid \\
\hline $0 \%-39 \%$ & Invalid \\
\hline
\end{tabular}

\section{RESUltS AND DisCUSSION}

\section{A. Research Result}

The validity of the student worksheet in solving the moralbased wetland problem can be seen as follows:

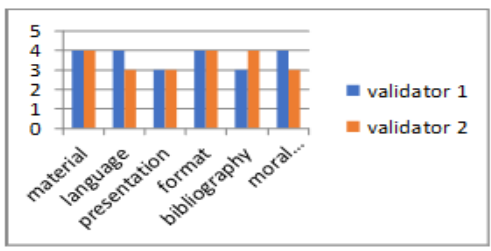

Fig. 1. Recapitulation of results of meeting student worksheet environmental pollution 


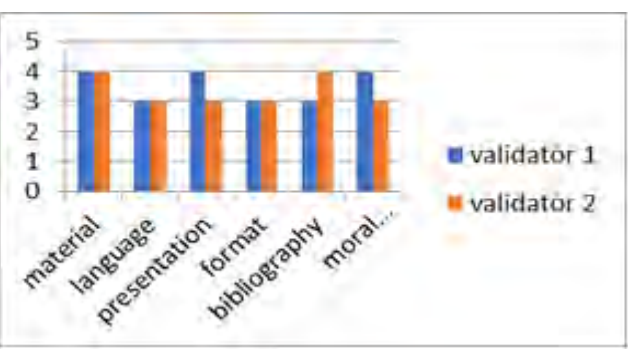

Fig. 2. Recapitulation of results of meeting student worksheet environmental conservation

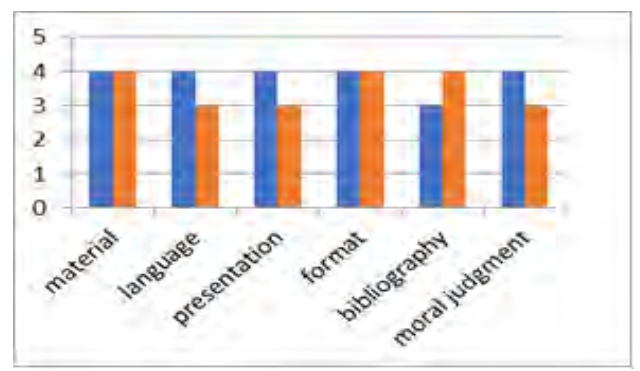

Fig. 3. Recapitulation of results of meeting student worksheet type of waste

Category description: $100-90 \%=$ very valid; $89-75 \%=$ valid; $74-65 \%=$ valid enough; $64-40 \%=$ less valid; $39-0 \%=$ invalid [3].

\section{B. Discussion}

Based on the three graphs above, it can be assumed that student worksheet was validated by the validators based on five aspects. The first aspect is the material in which validated material includes the truth of the content, systematic, and the relevance of the science. The environment gets an average score of 4 by validator 1 and validator two which shows that the model syntax is used, the truth of the content containing facts, concepts, scientific theories and processes and the linkages between science, technology, and society. A task ordered in the activity sheet must be clear of the competencies that will be achieved and can be used for any subject matter and objectives of the student worksheet compiler [4].

The purpose of preparing the student worksheet is to present teaching materials that make students more comfortable to interact with the material provided [5]. The second aspect of language is one of the indicators/aspects validated by validator 1 and validator two where the average score ranges from 3-3.5. The construction conditions include terms that are pleasing to the use of language, sentence structure, simplicity in the use of words and precise clarity in the meaning that students can understand [4]. Good language is by the maturity level of students, uses a clear sentence structure, has a sequence of lessons according to the child's ability level, and uses simple sentences [6].

The third aspect of the presentation here emphasizes whether or not the student worksheet generates motivation/interest/curiosity and attract or not the student worksheet. In evaluating this presentation the average score obtained from validator 1 and validator two ranges from 3 3.5. The student worksheet generates motivation/interest/ curiosity. In the preparation of printed teaching materials, it is essential to pay attention to student worksheet stimulants/attractiveness and ease of reading [4]. The next aspect is the format assessment aspect; this aspect emphasizes whether the student worksheet has been typed using 1.5 spaces with Times New Roman letters and 12 font sizes. From the results obtained both validator 1 and validator two average scores range from 3.5 - 4 which indicates that worksheet has been equipped with a worksheet key with a space of 15 , using Times New Roman letters and 12 font sizes. Aspects of letter accuracy (type and size, distance of letters/letters are bold / italics) that stand out and get attention to strengthen sentences to be delivered.

It is by the opinion of [5] that the use of bold letters and colours that are different from the primary colours will put pressure on the information to be conveyed. In addition, it is also necessary to pay attention to the rule for writing student worksheets. The technical requirements of writing use block letter and do not use Latin letter, use capital letters, without the underscore, then adjust the ratio of size letter to the image [4]. The fifth aspect of this bibliography emphasizes whether the bibliography is used more than $50 \%$ of the total library, both journals, and books, the year of publication is under ten years.

From the results of validator 1 and validator 2 , the average score obtained is 3.5 which means that $15 \%$ of the total literature, both journals, and books, are published under ten years. Bibliography with correct writing can make it easier for students to access more information from library sources [6]. The final aspect of the assessment of the student worksheet on moral-based problem solving emphasizes whether or not it supports the implementation of the teaching and learning process which refers to the syntax of solving problems that are morally controlled about the wetland environment. In this assessment, the average score obtained is 3.5 which means that it supports the implementation of the teaching and learning process which refers to the syntax of problem-solving. It is also according to the purpose of the preparation of the student worksheet to train the learning independence of participants in the education department [4].

\section{CONCLUSION}

The student worksheet in solving wetland problems based on moral dilemma developed in this research is very valid which total score of $91.6 \%$. The developed student worksheet can train students to solve moral-based environmental problems. This development research focuses only on student worksheet; it is better to develop other learning tools. In the next development, it should be used in other materials that are related to the conditions of residence of students so that it will be more useful and easy to apply to students

\section{REFERENCES}

[1] Depdiknas, Panduan Pengembangan Bahan Ajar. Jakarta: Direktorat Jenderal Manajemen Pendidikan Dasar dan Menengah Direktorat Pembinaan Sekolah Menengah Atas, 2008.

[2] M. Tessmer, Planning and Conducting - Formative Evaluations. London-Philadelphia: Kogan Page, 1998.

[3] S. Arikunto, Prosedur Penelitian: Suatu Pendekatan Praktek. Jakarta: RinekaCipta. Jakarta: Rineka Cipta, 2010. 
[4] Depdiknas, Pedoman Penyusunan Lembar Kegiatan Siswa dan Skenario Pembelajaran Sekolah Menengah Atas. Jakarta: Direktorat Pendidikan Dasar dan Menengah, 2004.

[5] A. Prastowo, Panduan Kreatif Membuat Bahan Ajar Inovatif. Yogyakarta: Diva, 2013.
[6] H. Savitri, F. Herlina, and P. Tarzan, "Pengembangan Lembar Kegiatan Siswa (LKS) Inkuiri Berbasis Berpikir Kritis Pada Materi Daur Biogeokimia Kelas X,” BioEdu, vol. 2, no. 1, pp. 99 - 104, 2013. 